\title{
Texture of Chanco cheese: Projection of a sensory map based on multivariate analysis
}

\author{
Javier Leiva ${ }^{1}$ and Heriberto Figueroa ${ }^{2}$ \\ 'Departamento de Ciencia y Tecnología de los Alimentos. ${ }^{2}$ Departamento de Ciencias Exactas, Universidad \\ de Los Lagos. Avenida Fuchslocher 1305, Osorno, Chile.
}

\begin{abstract}
J. Leiva, and H. Figueroa. 2010. Texture of Chanco cheese: Projection of a sensory map based on multivariate analysis. Cien. Inv. Agr. 37(1): 85-91. The aim of the study is to evaluate, by using sensory methods, Chanco cheese texture by means of quantitative descriptive analysis to project a sensory map based on multivariate analysis. Samples of Chanco cheese (two different commercial brands) were used. Sensory evaluation was undertaken by a trained panel $(\mathrm{n}=13)$, using quantitative descriptive analysis. The sensory profile includes the properties of springiness, hardness, friability, deformability, adhesiveness and cohesiveness. Sensory scales from one to seven were used to express the intensity perceived for each property. Based on the results, it was possible to observe the formation of a main group, comprising of cohesiveness, friability, springiness and adhesiveness. Other groupings were formed with hardness and deformability. From the results, it can be concluded that the sensory properties shown in the Chanco cheese sensory map provide information with regard to the solid state (hardness, deformability, friability) and fluidity (cohesiveness, adhesiveness, springiness) of the cheese. The map can serve as a practical tool for the evaluation of sensory properties of texture in quality control and may also be applied in terms of products development.
\end{abstract}

Key words: Chanco cheese, cheese, sensory map, sensory property, texture.

\section{Introduction}

Cheeses are identified their specific sensory attributes, which are widely appreciated by consumers (Barcenas et al., 2004). In addition, the traditional character of a cheese and its designation of origin are two of the most important factors influencing consumers' preference in the market (Bertozzi and Panari, 1993).

Texture, color, taste, aroma and visual appearance can be used to define the sensory food

Received 13 April 2009. Accepted 30 July 2009. Corresponding Author: j.leiva@ulagos.cl quality (Di Monaco et al., 2008). Previous studies have reported the chemical characterization (Barría, 1995) and structural (Leiva et al., 2009) characterization of Chanco cheese. However, few studies have covered deeply the sensory characterization of this type of cheese in depth (Vega, 2002; Arteaga, 2004).

The textural properties of cheeses may also be measured through a texture profile analysis (TPA) using a TA-XT2i texture analyzer (Stable Micro Systems) (O’Mahony et al., 2005; Figueroa, 2006). Recently, research has focused on characterizing cheese varieties using different sensory methodologies. Descriptive sensory analysis (Barcenas et al., 2001a; Barcenas et al., 2003a) and free profiles (Barcenas et al., 2003b) 
have been used to characterize cheeses made from with sheep milk. According to Risvik et al. (1994), sensory projection may be a technique potentially used for sensory analysis and to study consumer preferences. Another study evaluates profiles and sensory maps 49 (Risvik et al., 1997) and shows that the sensory maps were visually alike.

According to Muir et al. (1995), when trying to identify key sensory attributes in hard cheeses, a perceptual map should be built in a small space. Millán et al. (1996) worked with Spanish cheeses and discriminant analysis for physicochemical variables, which allowed them to detect subtle and intricate differences between the different Spanish cheeses even though the sensory differences were marked.

Independent of these advantages, the sensory profile is mainly criticized because the grouping of individual sensory elements does not necessarily represent what is really sensed. Because actual senses are not represented, the words of consumers may not describe what is being sensed (Murray et al., 2001). To have a more accurate understanding of this negative situation other techniques, such as the Direct Similarity Measurement (DSM) and hedonic measurements, have been proposed to compare different varieties of cheeses (Barcenas et al., 1998, 2001b, 2003b). Several studies dealing with different methodologies of sensory comparison state that multidimensional maps of the answers of consumers may be considered helpful tools in analyzing (Heymann, 1994; Gilbert and Heymann, 1995; Risvik et al., 1997). According to Dijksterhuis (1995), the use of multivariate methods to explore the structure of sensory data might become useful.

Consequently, the objective of this research was to evaluate the texture of Chanco cheese to project a sensory map based on a multivariate analysis based on sensory information and a descriptive quantitative analysis.

\section{Materials and methods}

\section{Selection of cheeses}

Samples of two different commercial brands of Chanco cheese were used in this study. Three samples per cheese brand were taken at random at 21 days of maturation (INN, 1961, 1999). All samples were stored at $5 \pm 1{ }^{\circ} \mathrm{C}$.

\section{Chemical analysis}

For each cheese sample, the $\mathrm{pH}$, fat content, humidity, total solids and salt content were determined after two individual analyses were conducted. The $\mathrm{pH}$ was determined following a potenciometric method (INN, 1979a). The fat content was measured according to the Gerber van Gulik method (INN, 1979b). The humidity and total solids content were determined by thermogravimetry (INN, 1978; IDF/FIL, 1982), and the salt level was determined using the Volhard method (AOAC, 2000).

\section{Sensory analysis}

The sensory evaluation was performed using a descriptive quantitative analysis and a trained panel ( $\mathrm{n}=13$ ) (Castañeda et al., 2007). The sensory profile of texture included the following properties: springiness (ability to recover its initial thickness rapidly after compression and deformation), firmness (resistance that the sample presents with small displacements of the jaws), friability (ability to generate several pieces from the beginning of chewing), deformability (ability of the sample to deform successively or stretch easily before breaking the sample in the buccal cavity), adhesiveness (moving the tongue to detach the sample stuck in the palate 
or teeth), and cohesiveness (firmness of the internal joints in the cheese sample).

A continuous, one (minimum) to seven (maximum), scale was used to estimate the intensity sensed for each property. The panelists worked individually with two samples per session, analyzing each sample twice. Before the evaluation, the samples were stabilized for $1 \mathrm{~h}$ at $15 \pm$ $1^{\circ} \mathrm{C}$, placed inside a closed Petri dish and cut in pieces of $1.5 \times 2.0 \times 7.0 \mathrm{~cm}$. The samples were identified with three numbers chosen at random, and the code was different for each test.

\section{Statistical analysis}

The results were subjected to an analysis of correlation, a cluster analysis and an analysis of correspondence (Pérez, 2004) using the Statistica 6.0 (StatSoft Inc., Tulsa, USA, 2004).

\section{Results and discussion}

The humidity, fat content, total solids content and $\mathrm{pH}$ of the Chanco cheese (Table 1) were similar to the results reported by the Chilean Official Standard 2090 (INN, 1999), and the salt content was similar to the indications given by Brito et al. (1989).

Table 1. Chemical characterization of two Chanco cheeses, sampled at 21 days of ripening.

\begin{tabular}{lcc}
\hline & \multicolumn{2}{c}{ Cheese samples $^{1}$} \\
\cline { 2 - 3 } Chemical parameters & A & B \\
\hline Humidity, \% & $39.56 \pm 2.21$ & $42.88 \pm 0.11$ \\
Fat content, \% & $27.75 \pm 3.75$ & $27.50 \pm 6.50$ \\
Salt level, \% & $0.86 \pm 0.20$ & $0.92 \pm 0.09$ \\
Total solid, \% & $60.44 \pm 2.21$ & $57.12 \pm 0.11$ \\
pH & $5.44 \pm 0.12$ & $5.66 \pm 0.54$ \\
\hline
\end{tabular}

${ }^{1}$ Means of three replicates. \pm Standard deviation.
Positive and significant correlations at $\mathrm{p}<0.05$ were obtained between cohesiveness and springiness, as well as between friability and adhesiveness (Table 2). The cohesiveness presented a highly significant coefficient of correlation with friability, whereas springiness and adhesiveness showed a close association with friability and cohesiveness, respectively. Chevanan et al. (2006), studying the effect of calcium on the texture properties of Cheddar cheese, found a direct proportionality between springiness and cohesiveness as well as an inverse relation between these two properties and adhesiveness. Similarly, Everard et al. (2007) indicate that the relationship between springiness and adhesiveness is inversely proportional during the process of syneresis of the curd granules.

Table 2. Correlations between sensory properties used to profile the samples of Chanco cheese'.

\begin{tabular}{lcccccc}
\hline Sensory properties & S & H & F & D & A & C \\
\hline Springiness (S) & 1.00 & & & & & \\
Hardness (H) & -0.29 & 1.00 & & & & \\
Friability (F) & 0.61 & 0.21 & 1.00 & & & \\
Deformability (D) & -0.34 & 0.14 & -0.47 & 1.00 & & \\
Adhesiveness (A) & 0.49 & -0.16 & $0.64^{1}$ & -0.67 & 1.00 & \\
Cohesiveness (C) & $0.70^{1}$ & 0.00 & $0.86^{1}$ & -0.40 & 0.66 & 1.00 \\
\hline
\end{tabular}

${ }^{1}$ Significant correlation at $\mathrm{p}<0.05$.

Lawrence et al. (1987) find that the best cohesiveness in the curd granules shows a $\mathrm{pH}$ close to 5.2. Based on the results obtained in our study, the $\mathrm{pH}$ varied between 5.4 and 5.6 in the samples of the Chanco cheese tested, confirming the high correlation shown by cohesiveness. Leiva et al. (2009), characterizing the structure of Chanco cheese, found that some sensory properties (cohesiveness, firmness, deformability) and chemical parameters (humidity, $\mathrm{pH}$, salt level, total solids) were part of the macrostructure, which determines how the curd granules 
fuse and how they are sensed by the consumer. Lawlor et al. (2001) indicate that cohesiveness and firmness were closely correlated to $\mathrm{pH}$ and the chemical composition of cheeses. According to Pereira et al. (2006), sensory firmness and adhesiveness are satisfactorily correlated with the chemical data.

According to the dendogram (Figure 1), and regarding the level corresponding to six, a threshold point, three groups were formed with the six properties mentioned above. The first group was composed of two subgroups according to cohesiveness, friability and springiness, and adhesiveness, respectively. The second and third groups were formed on the basis of firmness and deformability, respectively.

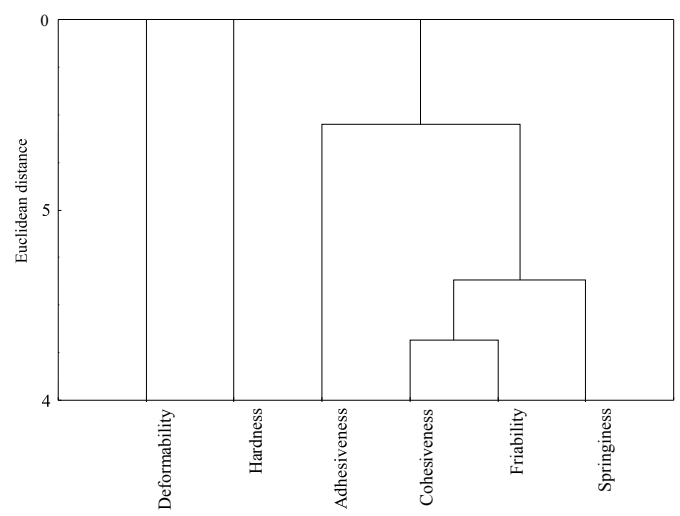

Figure 1. Dendrogram showing the clustering of the sensory properties of the Chanco cheese.

Figure 2 presents the analysis of correspondence, the location of the sensory properties and the positioning of the panelists in the same representation. It was observed that two dimensions were necessary to express $80.8 \%$ of the variability among the sensory properties, coinciding with the reports by Risvik et al. (1994), who obtained sensory maps alike at least visually, in the first two dimensions. Therefore, the localization of the sensory properties in the plane allowed us to find related groups. Thus, the close properties were sensed as similar and the far properties between one another as different.

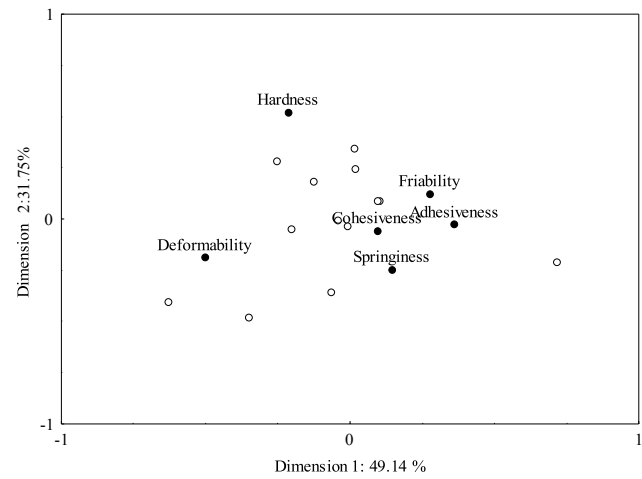

Figure 2. Texture map of panelists' data combined with the results of the sensory evaluation. (०) panelists, (•) sensory properties.

With regard to the information presented in Figure 1 and 2 , it can be deduced that by choosing the three sensory properties of the group formed by: friability, adhesiveness, cohesiveness and springiness besides hardness and deformability, information on the sensory aspect of texture may be obtained that is equivalent to the result from the six properties that were studied. Leiva et al. (2009), through a structural characterization of Chanco cheese, propose that the parameters of firmness, deformability and friability directly affect structural macro-scale details, thus providing information on the solid state or capacity of storing energy in the structure of cheese. In contrast, the parameters of cohesiveness, adhesiveness and springiness provide information on small structural features associated with the fluidity state or the capacity for releasing energy. In this study, friability (Figure 2) is linked to adhesiveness, cohesiveness and springiness. The sensory description probably did not clearly reflect what the panelists sensed with respect to friability.

Therefore, from a sensory perspective, Chanco cheese should not be characterized precisely by its firmness. Thus, the structural collapse (solid state) is more expected if the cheese presents a low fat content (Ritvanen et al., 2005). The foregoing would lead the texture to be harder, thus allowing the sample to fracture into pieces instead of remaining together as a cohesive mass. 
In addition, the cheese would not melt easily (Gwartney et al., 2002). On the contrary, the increase of the cheese's humidity might favor a higher fluidity in detriment to the firmness of the cheese (Everard et al., 2007).

Other cheeses have shown satisfactory results. Pagliarini et al. (1997), for example, obtains a good discrimination with three different mozzarella cheeses (whole cow milk, skimmed cow milk and whole buffalo milk) using preferred maps. In cheddar cheese, the perception of maturation from the panelists was discordant. However, the maturation sensed for that cheese was closely associated with its flavor intensity (Muir and Hunter, 1992). A sensory study of the cheddar cheese explains the differences in the texture of the product that was made from whole and skimmed milk (Banks et al., 1993).
The results showed minimum variability, mainly attributed to the presence of specific sensory training. To obtain interesting information and hinder inaccurate conclusions, the specific use of trained panelists is highly recommended.

Based on the results, we can conclude that the sensory map of the Chanco cheese sample and the properties of texture provide information about the solidity (firmness, deformability, friability) and fluidity (cohesiveness, adhesiveness, springiness) of the cheese. The map may be used as a helpful tool for the evaluation of the sensory properties of texture for quality control and applications in product development. An understanding of the chemical, structural and mechanical properties that determine each of the texture attributes of the cheese will be required to improve the texture of Chanco cheese.

\title{
Resumen
}

\begin{abstract}
J. Leiva y H. Figueroa. 2010. Textura de queso Chanco: proyección de un mapa sensorial basado en análisis multivariante.Cien. Inv.Agr.37(1): 85-91. El objetivo de la investigación fue evaluar sensorialmente la textura del queso Chanco mediante análisis descriptivo - cuantitativo, a fin de proyectar un mapa sensorial basado en análisis multivariante. Se emplearon muestras de queso Chanco (2 marcas comerciales distintas). La evaluación sensorial la realizó un panel entrenado ( $\mathrm{n}=13)$, mediante un análisis descriptivo - cuantitativo. El perfil sensorial abarcó las propiedades: elasticidad, firmeza, friabilidad, deformabilidad, adhesividad y cohesividad. Se emplearon escalas sensoriales de 1 a 7 , para expresar la intensidad percibida en cada propiedad. Los resultados obtenidos permitieron observar la formación de un grupo principal conformado por la cohesividad, friabilidad, elasticidad y adhesividad. Otros agrupamientos se formaron con la firmeza y deformabilidad. Basado en los resultados del estudio, se concluye que el mapa sensorial del queso Chanco muestra las propiedades sensoriales que entregan información acerca del estado de solidez (firmeza, deformabilidad, friabilidad) y fluidez (cohesividad, adhesividad, elasticidad) en el queso. El mapa puede ser usado como una herramienta útil, para la evaluación de propiedades sensoriales de textura, en control de calidad y aplicaciones de desarrollo de productos.
\end{abstract}

Palabras clave: Mapa sensorial, propiedad sensorial, queso Chanco, textura.

\section{References}

Arteaga, M. 2004. Evolución de la maduración del queso Chanco elaborado con acidificación de suero en polvo. Tesis Magíster en Ciencias y Tecnología de la Leche. Facultad de Ciencias
Agrarias, Universidad Austral de Chile. Valdivia, Chile. 256 pp.

AOAC. 2000. Official Methods of Analysis. 17 $7^{\text {th }}$ ed. Association of Official Analytical Chemists, Gaithersburg, MD.

Banks, J.M., E.A. Hunter, and D.D. Muir. 1993. Sensory properties of low fat Cheddar cheese: effect 
of salt content and adjunct culture. Int. J. Dairy Technol. 46:119-123.

Barcenas, P., F.J. Pérez Elortondo, and M. Albisu. 2003a. Sensory changes during ripening of an ewes milk cheese manufactured with and without the addition of a starter culture. J. Food Sci. 68:2572-2578.

Barcenas, P., F.J. Pérez Elortondo, and M. Albisu. 2003b. Comparison of free choice profiling, direct similarity measurements and hedonic data for ewes' milk cheese sensory evaluation. Int. Dairy J. 13:67-77.

Barcenas, P., F.J. Pérez Elortondo, and M. Albisu. 2004. Projective mapping in sensory analysis of ewes milk cheeses: A study on consumers and trained panel performance. Food Res. Int. 37:723-729.

Barcenas, P., F.J. Pérez Elortondo, J. Salmeron, and M. Albisu. 1998. Recalled preference of Spanish consumers for smoked food. Nutrition and Food Science. 6:338-342.

Barcenas, P., F.J. Pérez Elortondo, J. Salmeron, and M. Albisu. 2001a. Sensory profile of ewe's milk cheeses. Food Sci. Technol. Int. 7:347-353.

Barcenas, P., R. Pérez San Roman, F.J. Pérez Elortondo, and M. Albisu. 2001b. Consumer preference structures for traditional Spanish cheeses and their relationship with sensory properties. Food Qual. Prefer. 12:269-279.

Barría, M. 1995. Características de Composición, Sensoriales y Grado de Maduración del Queso Chanco. Tesis Licenciado en Ciencias de los Alimentos. Facultad de Ciencias Agrarias, Universidad Austral de Chile. Valdivia, Chile. 126 pp.

Bertozzi, L., and G. Panari. 1993. Cheeses with Appellation d'Origine Controlée (AOC). Factors that affect quality. Int. Dairy J. 3:297-312.

Brito, C., H. Jofré, L.H. Molina, G. Oettinger, y J. Haverbeck. 1989. Diagnóstico de la Producción Actual de Queso Chanco de Campo y Desarrollo de Tecnologías Intermedias Para su Producción (1985-1991). Informe 4 ${ }^{\mathrm{a}}$ etapa. Ministerio de Agricultura - Universidad Austral de Chile. 128 pp.

Castañeda, R., C. Cañameras, G. Aranibar, and H. Montero. 2007. La textura del Queso Goya. Comparación entre el método sensorial y métodos reológicos. http://www4.inti.gov.ar/GD/5jornadas/ doc/178.doc (Accessed: December, 2007).

Chevanan, N., K. Muthukumarappan, P. Upreti, and L.E. Metzger. 2006. Effect of calcium and phosphorus, residual lactose and salt-to-moisture ratio on textural properties of Cheddar cheese during ripening. J. Texture Stud. 37:711-730.

INN. 1961. Selección de muestras al azar. Norma Chilena 43. Instituto Nacional de Normalización (INN), Santiago, Chile.

INN. 1978. Alimentos. Determinación de Humedad. Norma Chilena 841. Instituto Nacional de Normalización (INN), Santiago, Chile.

INN. 1979a. Leche y productos lácteos. Determinación de $\mathrm{pH}$. Norma Chilena 1671. Instituto Nacional de Normalización (INN), Santiago, Chile.

INN. 1979b. Leche. Determinación del contenido de Materia Grasa. Método de Gerber. Norma Chilena 1016. Parte I. Instituto Nacional de Normalización, Santiago, Chile

INN. 1999. Productos lácteos. Queso Chanco. Requisitos. Norma Chilena 2090. Instituto Nacional de Normalización (INN), Santiago, Chile.

Di Monaco, R., S. Cavella, and P. Masi. 2008. Predicting sensory cohesiveness, hardness and springiness of solid foods from instrumental measurements. J. Texture Stud. 39:129-149.

Dijksterhuis, G. 1995. Review. Multivariate data analysis in sensory and consumer science: An overview of developments. Trends Food Sci. Tech. 6:206-211.

Everard, C.D., C.C. Fagan, C.P. O’Donnell, D.J. O’Callaghan, M. Castillo, and F.A. Payne. 2007. Computer vision and colour measurement techniques for inline monitoring of cheese curd syneresis. J. Dairy Sci. 90:3162-3170.

Figueroa, J. 2006. Perfil textural de queso Chanco comercial elaborado en tres regiones de Chile. Tesis Licenciado en Ciencias de los Alimentos. Facultad de Ciencias Agrarias, Universidad Austral de Chile. Valdivia, Chile. 110 pp.

Gilbert, J.M., and H. Heymann. 1995. Comparison of four sensory methodologies as alternatives to descriptive analysis for the evaluation of apple essence aroma. The Food Technologist 24:28-32.

Gwartney, E.A., E.A. Foegeding, and D.K. Larick. 2002. The texture of commercial full-fat and reduced-fat cheese. J. Food Sci. 67:812-816.

Heymann, H. 1994. A comparison of free choice profiling and multidimensional scaling of vainilla samples. J. Sens. Stud. 9:445-453.

IDF/FIL. 1982. Cheese and processed cheese. Determination of the solids content (reference method). International Dairy Federation, IDF FIL 4-A:1982.

Lawlor, J., C. Delahunty, M. Wilkinson, and J. Sheehan. 2001. Relationships between the sensory characteristics, neutral volatile composition and 
gross composition of ten cheese varieties. Le Lait, Dairy Science and Technology. 81:487507.

Lawrence, R.C., L.K. Creamer, and J. Gilles. 1987. Symposium: cheese ripening technology. Texture development during cheese ripening. J. Dairy Sci. 70:1748-1760.

Leiva, J., H. Magariños, A. Romero, and H. Figueroa. 2009. Caracterización estructural mediante análisis de imagen del queso Chanco elaborado en la Provincia de Osorno. Agro Sur 37(1):26-33.

Millán, R., P. Saavedra, E. Sanjuán, and M. Castelo. 1996. Application of discriminant analysis to physicochemical variables for characterizing Spanish cheeses. Food Chem. 55189-191.

Muir, D.D., and E.A. Hunter. 1992. Sensory evaluation of Cheddar cheese: the relation of sensory properties to perception of maturity. Int. J. Dairy Technol. 45:23-30.

Muir, D.D., E.A. Hunter, J.M. Banks, and D.S. Horne. 1995. Sensory properties of hard cheese: identification of key attributes. Int. Dairy J. 5:157-177.

Murray, J.M., C.M. Delahunty, and I.A. Baxter. 2001. Descriptive sensory analysis: past, present and future. Food Res. Int. 34:461-471.

O’Mahony, J.A., J.A. Lucey, and P.L.H. McSweeney. 2005. Chymosin-mediated proteolysis, calcium solubilization, and texture development during the ripening of Cheddar cheese. J. Dairy Sci. 88: 3101-3114.
Pagliarini, E., E. Monteleone, and I. Wakeling. 1997. Sensory profile description of Mozzarella cheese and its relationship with consumer preference. J. Sens. Stud. 12:285-301.

Pereira, R., L. Matia-Moreno, V. Jones, and H. Singh. 2006. Influence of fat on the perceived texture of set acid milk gels: a sensory perspective. Food Hydrocolloids 20(2-3):305-313.

Pérez, C. 2004. Técnicas de Análisis Multivariante de Datos. Aplicaciones con SPSS. Pearson Prentice-Hall. España. 646 pp.

Risvik, E., J.A. McEwan, and M. Rodbotten. 1997. Evaluation of sensory profiling and projective mapping data. Food Qual. Prefer. 8:63-71.

Risvik, E., J.A. McEwan, J.S. Colwill, R. Rogers, and D.H. Lyon. 1994. Projective mapping: a tool for sensory analysis and consumer research. Food Qual. Prefer. 5:263-269.

Ritvanen, T., S. Lampolahti, L. Lilleberg, T. Tupasela, M. Isoniemi, and U. Appelbye. 2005. Sensory evaluation, chemical composition and consumer acceptance of full fat and reduced fat cheeses in the Finnish market. Food Qual. Prefer. 16:479492.

Vega, L. 2002. Influencia del uso de imitadores de grasa sobre el proceso de elaboración y rendimiento de queso Chanco de reducido tenor graso. Tesis Licenciado en Ingeniería en Alimentos. Facultad de Ciencias Agrarias, Universidad Austral de Chile. Valdivia, Chile. 206 pp. 
